\title{
Reproductive biology of little tunny Euthynnus alletteratus (Rafinesque, 1810) in the southwest Gulf of Mexico
}

\author{
Roberto Cruz-Castán ${ }^{1,2}$ ， César Meiners-Mandujano ${ }^{2}$ ， David Macías ${ }^{3}$ ， Lourdes Jiménez-Badillo ${ }^{2}$, Sergio \\ Curiel-Ramírez ${ }^{\text {Corresp. } 4}$ \\ 1 Posgrado en Ecología y Pesquerías, Universidad Veracruzana, Boca del Río, Veracruz, Mexico \\ 2 Instituto de Ciencias Marinas y Pesquerías, Universidad Veracruzana, Boca del Río, Veracruz, Mexico \\ 3 Centro Oceanográfico de Málaga, Instituto Español de Oceanografía, Fuengirola, Malaga, Spain \\ 4 Instituto de Investigaciones Oceanológicas, Universidad Autónoma de Baja California, Ensenada, Baja California, Mexico \\ Corresponding Author: Sergio Curiel-Ramírez \\ Email address: curiels@uabc.edu.mx
}

The aim of this study was to describe the reproductive dynamic of Euthynnus alletteratus in the southwest Gulf of Mexico. The annual variation of the volume fraction occupied by gametes and tissues in gonads were related with main body indexes, such as the gonadosomatic index $\left(I_{G}\right)$, the hepatosomatic index $\left(I_{H}\right)$, and the nutrition index $\left(I_{N}\right)$, and compared with the sea surface temperature (SST). A total of 951 E. alletteratus individuals were sampled, where a sex ratio of 1:1 and a size interval strongly skewed towards organisms with a fork length $\left(L_{F}\right)$ of 36 to $40 \mathrm{~cm}$ were observed. The $I_{G}$ showed an increase from March to September with maximum values in April and July. Two clearly defined peaks were observed, and they were consistent with the histological analysis, where the percentage of ripe gametes predominated from April to September. The optimum thermal window for reproductive activity was from 24 to $28{ }^{\circ} \mathrm{C}$. The size of first sex maturity was $34.35 \mathrm{~cm}$ of fork length $\left(L_{F}\right)$ for males and $34.60\left(L_{F}\right)$ for females, without significant difference between sexes. 


\section{Reproductive biology of little tunny Euthynnus}

2 alletteratus (Rafinesque, 1810) in the southwest Gulf

3 of Mexico.

4

5

6

7

8

Roberto Cruz-Castán ${ }^{1,2}$, César Meiners-Mandujano², David Macías ${ }^{3}$, Lourdes Jiménez-Badillo², Sergio Curiel-Ramírez ${ }^{4}$

${ }^{1}$ Posgrado en Ecología y Pesquerías, Universidad Veracruzana, Boca del Río, Veracruz, Mexico ${ }^{2}$ Instituto de Ciencias Marinas y Pesquerías, Universidad Veracruzana, Boca del Río, Veracruz, Mexico

${ }^{3}$ Centro Oceanográfico de Málaga, Instituto Español de Oceanografía, Fuengirola, Málaga, Spain

${ }^{4}$ Instituto de Investigaciones Oceanológicas, Universidad Autónoma de Baja California, Ensenada, Baja California, Mexico

Corresponding Author:

Sergio Curiel-Ramírez ${ }^{4}$

Carretera Ensenada-Tijuana № 3917 Fraccionamiento Playitas, Ensenada, Baja California, Zip code 22860, México

Email address: curiels@uabc.edu.mx scurie173@gmail.com

\section{Abstract}

The aim of this study was to describe the reproductive dynamic of Euthynnus alletteratus in the southwest Gulf of Mexico. The annual variation of the volume fraction occupied by gametes and tissues in gonads were related with main body indexes, such as the gonadosomatic index $\left(I_{G}\right)$, the hepatosomatic index $\left(I_{H}\right)$, and the nutrition index $\left(I_{N}\right)$, and compared with the sea surface temperature (SST). A total of 951 E. alletteratus individuals were sampled, where a sex ratio of 1:1 and a size interval strongly skewed towards organisms with a fork length $\left(L_{F}\right)$ of 36 to $40 \mathrm{~cm}$ were observed. The $I_{G}$ showed an increase from March to September with maximum values in April and July. Two clearly defined peaks were observed, and they were consistent with the histological analysis, where the percentage of ripe gametes predominated from April to September. The optimum thermal window for reproductive activity was from 24 to $28{ }^{\circ} \mathrm{C}$. The size of first sex maturity was $34.35 \mathrm{~cm}$ of fork length $\left(L_{F}\right)$ for males and $34.60\left(L_{F}\right)$ for females, without significant difference between sexes. 


\section{Introduction}

41 The little tunny (Euthynnus alletteratus, Rafinesque 1810) is an epipelagic and neritic fish (Chur,

42

43

44

45

46

47

48

49

50

51

52

53

54

55

56

57

58

59

60

61

62

63

64

65

66

67

68

69

70

71

72

73

74

75

76

77

78

79
1973) distributed on both sides of the tropical and subtropical Atlantic Ocean, including the Mediterranean Sea, the Black Sea, the Caribbean Sea, and the Gulf of Mexico (Belloc, 1955; Collette \& Nauen, 1983; Valeiras \& Abad, 2006). It is the smallest of the tunids and grows to a maximum weight of $16.5 \mathrm{~kg}$ and a total length of $122 \mathrm{~cm}$ fork length $\left(L_{F}\right)$ (Froese \& Pauly, 2014). As a target species, it is historically valued and captured seasonally by coastal trawling fleets in western Africa, the Gulf of Cadiz, and the Mediterranean Sea (Sabatés \& Recasens, 2001; Neves dos Santo \& García, 2006; Gaycov \& Bokhanov, 2008; Kahraman, 2005; Zengin \& Karakulak, 2009). It is also captured incidentally in important quantities by industrial trawling and purse seine fleets between Mauritania and Angola (Gaycov \& Bokhanov, 2008). In the southern Gulf of Mexico, E. alletteratus is considered a secondary target species and captured mainly by the multispecific artisanal fishery for the local market and as bait (Cabrera et al., 2005). For its capture, different fishing gears such as gillnets, drift nets, surface long-lines, and hand lines with bait or trolling are used, depending on the locality (Cabrera et al., 2005; JiménezBadillo et al., 2006).

Currently, direct or incidental capture of little tunny developed in the Gulf of Mexico is not subject to fishing control or specifications, and there are no estimates of the stock size of this species in the Gulf of Mexico. Information about its structure population is scarce and fragmented, which prevents adequate assessment of the stock (Valeiras \& Abad, 2006). The conservation and management strategies of tuna stocks require updated and specific information about their reproductive biology; this allows the establishment of exploitation criteria that contribute to adequate management scenarios for this species.

Most studies about the biology of E. alletteratus have taken part along its eastern distribution, referring to the size at first maturity, body indexes, fecundity, sex ratio, spawning periods, age and growth, somatic growth, size structure, and trophic ecology (Frade \& Postel, 1955; Landau, 1965; Rodríguez-Roda, 1966, 1979; Diouf, 1981; Cayré \& Diouf, 1983; Kahraman \& Oray, 2001; Kahraman, 2005; Macías et al., 2006; Bahou et al., 2007; Falutano et al., 2007; Kahraman et al., 2008; Macías et al., 2009; Hajjej et al., 2010a). In contrast, and despite of its extensive geographical distribution and regional fisheries importance, the biology of E. alletteratus has been studied scarcely along the western Atlantic margin (Manooch et al., 1985; Cabrera et al., 2005; García \& Posada, 2013).

Fish reproduction is a complex physiological process, markedly seasonal. It is a result of environmental information incorporated by the fish and transmitted by hormones, with the objective of reproducing only in the most favorable temporal and spatial window to maximize the survival of the progeny (Muñoz et al., 2005). In spite of the fact that E. alletteratus is a conspicuous component in artisanal fisheries of the southwest Gulf of Mexico throughout the year, there is no scientific and updated information about its reproductive biology in this area. Therefore, the aim of this study was to describe the reproductive biology of E. alletteratus fished in the southwest Gulf of Mexico, by analyzing their sex ratio, the size at first maturity and the 
80 reproductive cycle with the use of body indexes and the annual variation of the volume fraction

81 occupied by gametes in gonads. Furthermore, we examined the relationship between sea surface

82 temperature (SST) and reproductive activity by months.

83

84 Materials \& Methods

85

86

87

88

89

90

91

92

93

94

95

96

97

98

99

100

101

102

103

104

105

106

107

108

109

110

111

112

113

114

Sampling. From December 2009 to November 2012, artisanal commercial catch-based samplings of Euthynnus alletteratus were conducted in the southwest Gulf of Mexico, particularly for the area between the north of the Veracruz Reef System and Punta Roca Partida, in the Mexican state of Veracruz (Fig. 1). Sampling periodicity varied between four and twelve weeks, according to availability of E. alletteratus captures that were landed in Antón Lizardo and Las Barrancas at the municipality of Alvarado. The collected organisms were transported to the laboratory for biological processing.

Macroscopic analysis. Each specimen was measured at $0.1 \mathrm{~cm}$ closer to fork length $\left(L_{F}\right)$ and weighed $( \pm 0.1 \mathrm{~g})$. The sex, and weight of the gonads and livers ( $\pm 0.001 \mathrm{~g})$ were registered, and the sex maturity was determined macroscopically within six stages according to the characteristics observed in gonads (Table 1).

To obtain size structure, the data were grouped in size classes of intervals of $5 \mathrm{~cm}$ of $L_{F}$, then the sex ratio was calculated by size class and coefficient of variation (CV) through nonparametric bootstrap using the library "inbio 1.2" (Sampedro et al., 2005) in the R software; additionally, a chi-squared test was performed to determine if the sex ratio is equal.

Gonado-somatic index $\left(I_{G}\right)$ and the hepato-somatic index $\left(I_{H}\right)$ were calculated according to the relation of the weight of the gonad and the liver regarding to the total weight of each organism, as described in Introzzi \& De Introzzi (1986):

$$
I_{G}=\frac{\text { Gonad weight }}{\text { Total weight }- \text { Gonad weight }} \cdot 100
$$

$$
I_{H}=\frac{\text { Liver weight }}{\text { Total weight }- \text { Liver weight }} \cdot 100
$$

Nutritional index $\left(I_{N}\right)$ was calculated from a modification of the condition factor or Fulton index (K) proposed by Nikolsky (1963), using the weight without viscera rather than the total weight to correct for the effect of the reproductive state of the organisms (Granado-Lorencio, 1996):

$$
I_{N}=\frac{\text { Eviscerated weight }}{\text { Fork lenght }}{ }^{3} \cdot 100
$$


115 Length at first maturity $\left(L_{50}\right)$ by sexes was determined from the ogive of maturity by classes with 116 a fork length of $5 \mathrm{~cm}\left(L_{F}\right)$ through the fitting to the logistic model proposed by Bakhayokho 117 (1983):

$$
P=\frac{1}{1+e^{-\left(a+b L_{F}\right)}}
$$

119

The fitting process was done by applying a General Linear Model (GLM) with binomial errors (logistical regression) and solved with nonparametric bootstrap through the library inbio 1.2 (Sampedro et al., 2005) using the R software.

123

Microscopic Analysis. For establishing the reproductive cycle of E. alletteratus, a total of 155 gonads (58 male and 97 female) were analyzed from samplings received from December 2011 to November 2012. The gonads of each tuna were fixed in Davidson's fixative solution (Shaw \& Batle, 1957) and sections of $5 \mu \mathrm{m}$ were histologically processed by cutting and staining with hematoxylin and eosin, adhering to specific staining times for E. alletteratus (Cruz-Castán et al., 2014). The average volume fraction ( $V v)$ occupied by different cells was determined by quantitative stereology, using the Weibel microscope reticle (Weibel et al., 1966) with 42 points and following the methodology described by Briarty (1975) that was applied in other aquatic organisms by several authors (Lowe et al., 1982; Seed \& Suchanek, 1992; Cáceres-Martínez \& Figueras, 1998; Curiel-Ramírez \& Cáceres-Martínez, 2004, 2012). Under the microscope, we conducted five random counts in each histological slide. The main components $(x i)$ were identified and classified according to the cellular characteristics detailed in table 2; the fraction volume occupied by each component were then expressed in percentages with:

$$
V_{V}=\frac{\Sigma x i}{210} \cdot 100
$$

138

Sea surface temperature. Monthly data of sea surface temperature (SST) were obtained from the telematics interface for the visualization and analysis of data of "Giovanni" remote perception from a satellite with a spatial resolution of $4 \mathrm{~km}$ from December 2009 to November 2012. A temporal series of the monthly average of the SST was built from a regular polygon that included the area of the captures. The temporal evolution of the SST was contrasted against the $I_{G}$ of $E$. alletteratus to value the degree of temporal coincidence. To determine if there is a correlation between reproductive activity and temperature, a Pearson correlation analysis was performed.

\section{Results}

147 A total of 951 organisms were collected, with an average body length of $41.68 \mathrm{~cm} L_{F}( \pm 7.52$ $148 \mathrm{~cm})$ and an average weight of $1196.48 \mathrm{~g}( \pm 861.37 \mathrm{~g})$. Table 3 shows details regarding the body 149 length and weight by sexes.

150 The distribution of length frequency was strongly skewed towards a length interval of $36 \mathrm{~cm}$ to $15140 \mathrm{~cm} L_{F}$ (Fig. 2). 
152 Even though the sex ratio of this species is 1:1 in global terms $\left(\chi^{2}=0.668, \mathrm{P}>0.05\right)$, a greater

153

154

155

156

157

158

159

160

161

162

163

164

165

166

167

168

169

170

171

172

173

174

175

176

177

178

179

180

181

182

183

184

185

186

187

188

189

190

191

ratio of males in the length range of 28 and $30 \mathrm{~cm} L_{F}$ and above $65 \mathrm{~cm}$ of $L_{F}$ was observed. Females were clearly dominant in the length range of 45 and $50 \mathrm{~cm} L_{F}$ (Fig. 3).

Both for males and females, there was a marked increase in the gonado-somatic index $\left(I_{G}\right)$ from April which extended up to September, with fluctuations along these months; maximums were found in April and July and minimums from October to February. In contrast, the hepato-somatic index $\left(I_{H}\right)$ was highest in December, decreased notoriously up to March, and increased again from April to September with slight fluctuations. Nutritional index $\left(I_{N}\right)$ had highest values in April and October with fluctuations along the rest of the months (Fig. 4).

The length at first sexual maturity was $34.35 \mathrm{~cm} L_{F}$ for males and $34.60 \mathrm{~cm} L_{F}$ for females; in a combined analysis, the length at first maturity for males and females was $34.40 \mathrm{~cm} L_{F}$ (Fig. 5). Histologically, a temporal progression of the percentage of ripe gametes (RG) at population level (females and males) was observed, with maximum percentages ( $>60 \%)$ in May and July. The RG began to occupy a greater percentage of gonad volume in April, with $49.76 \pm 5.94 \%$, and decreased abruptly in October. Also, it is important to mention that during May and July, there was a marked decrease of free spaces (FS) in gonads (Fig. 6).

Comparing the evolution of SST at the study area and the $I_{G}$, a direct synchrony between the beginning of the increase of gonadic mass and the temperature was observed. At approximately $25^{\circ} \mathrm{C}$, a first maximum of $I_{G}$ was observed and around $28^{\circ} \mathrm{C}$, the main maximum of $I_{G}$ was reached; above this temperature, the process was deactivated (Fig. 7). Thus, the temporal evolution in the reproductive activity can be explained with a normal distribution with the majority fraction volume occupied by $R G$ in gonads from April to September $\left(\mathrm{R}^{2}=0.86\right)$ (Fig. 8).

\section{Discussion}

The maximum $L_{F}$ of Euthynnus alletteratus recorded in the current study $(80.7 \mathrm{~cm})$ was inferior to those reported by other authors for eastern Atlantic and western Mediterranean, e.g. $85 \mathrm{~cm} L_{F}$ (Macías et al., 2009), $97.8 \mathrm{~cm} L_{F}$ (Hajjej et al., 2010b), and $84 \mathrm{~cm} L_{F}$ (Valeiras et al., 2008). Regarding the minimum length, an individual of $28.2 \mathrm{~cm} L_{F}$ was registered, sensibly smaller than the minimum length reported for specimens sampled in the western Mediterranean, $32-56 \mathrm{~cm}$ $L_{F}$ (Valeiras et al., 2008; Macías et al., 2006); in the Gulf of Gabes, $34 \mathrm{~cm} L_{F}$ (Hajjej et al., 2010b), and in the eastern Atlantic, $31 \mathrm{~cm} L_{F}$ (Neves dos Santos \& García, 2006). This length difference could be attributed to the selectivity of fishing gears and to the latitudinal gradients in which this species is distributed. In spite of these regional differences, the length interval sampled in this study, is one of the broadest used for studies of reproduction of this species, and it includes specimens very near to the growth asymptote of E. alletteratus of the southwest Gulf of Mexico (Alcaráz-García, 2012).

Length distribution was multi-modal; however, there was a more notorious mode from $36 \mathrm{~cm}$ to $40 \mathrm{~cm} L_{F}$. The majority of the captures were carried out with gillnets of 3 inches mesh size, which had an influence on the proportion of capture for each length group. Macías et al. (2009) reported an influence of the fishing gear on length distribution of captures along the Spanish 
192 coasts. They compared tuna trap nets with coastal sport fishing with trolling and determined 193 multi-modal distributions for both methods which affected different length segments. For the 194 trap-nets, the interval of length was wider (62 to $85 \mathrm{~cm} L_{F}$ ), without a dominant mode on the 195 rest; in sport fishing, the interval was narrower ( 37 to $48 \mathrm{~cm} L_{F}$ ), with a predominant mode (41 $196 \mathrm{~cm} L_{F}$ ). In this study, the length spectrum was relatively wide, from juveniles to adults, which is 197 a fundamental condition for carrying out a precise description of the reproductive process of any 198 species.

199 The sex ratio is a sensible indicator of fish populations viability (Nikolsky, 1963; Santamaría-

200

201

202

203

204

205

206

207

208

209

210

211

212

213

214

215

216

217

218

219

220

221

222

223

224

225

226

227

228

229

230

231 Miranda \& Rojas-Herrera, 1997); a significant difference between the number of females vs males can be attributed to different survival rates or segregated sex distribution (Lucano-Ramírez et al., 2005), which results in mortality and growth rates differentiated by sex (Pascual et al., 2010). In the case of Euthynnus alletteratus in the southwest Gulf of Mexico, the population in global terms is in sex equilibrium (1:1), and the predominance of larger sized males is due to the fact that males reach greater lengths (Alcaráz-García, 2012). This finding is in agreement with other studies in tunids; for example, in albacore (Thunnus alalunga) fisheries in the western Mediterranean Sea, the number of females decreased for the greater sizes (Saber et al., 2015a). According to the temporal evolution of $I_{G}$, the reproductive period of $E$. alletteratus in the southwest Gulf of Mexico starts in April and extends to September. This reproductive period of E. alletteratus is similar to the described by Posada-Peláez et al. (2012) who determined that for the Colombian Caribbean region, the first spawning take place in April-June and the second and the most intense, during August-September. On the other hand, Diouf (1981) recorded a reproduction period between July and September along the coasts of Senegal; while in the Mediterranean Sea, both western and eastern, spawning occurs from May to September (Collette \& Nauen, 1983; Kahraman et al., 2008), with an $I_{G}$ maximum in July, which coincides with the maximum found in this study. However, this study clearly proves the existence of two well differentiated $I_{G}$ peaks within an extended reproductive period, which indicates a particular reproduction strategy of E. alletteratus in the southwest Gulf of Mexico compared to populations in the eastern Atlantic and Mediterranean Sea where a less extended reproductive peak has been reported. Furthermore, the two $I_{G}$ peaks were in agreement with the volume fraction occupied by RG in these months. In this sense, histological analysis was used as a complementary study in order to prevent a false conclusion; since a decrease in $I_{G}$ can be attributed to a spawning, but this decrease could be due to collect minor length individuals and a decrease in the gonad weight as a consequence, without been a spawning. The major proportion of FS, connective tissue (VCT) and unripe gametes (UG) correspond with a decrease of reproductive activity for this species.

The relation of variability between $I_{H}$ and $I_{N}$ with the development of reproductive activity $\left(I_{G}\right)$ showed from December to February, corresponds to the eve of the reproductive period. Besides, an inverse relation between the indexes for both sexes was observed, which suggests the relocation of energy resources from the liver and fatty bodies towards the reproductive system (Arellano-Martínez et al., 2001). However, during the reproductive period from April to 
232 September, with two clearly defined peaks in April and July, a direct relationship between $I_{H}, I_{G}$ $233 I_{N}$ was observed, suggesting that there was no evident energetic relocation and that the energy for 234 reproductive activity was provided by immediate feeding. During this period, tunas specialize in 235 a diet rich in the engraulid, Anchoa hepesetus (Bouchot-Alegría, 2012), a species with high fatty 236 content, which enables an increase in reproductive activity without the need of relocating energy 237 from the liver or the muscular tissues. Moreover, after the two maximum $I_{G}$ peaks, the $I_{N}$ 238 decreased, which suggests periods without feedings, with immediate recoveries for a following 239 spawning or energy accumulation for the following reproductive season. This could also be 240 demonstrated by the existence of constant availability of food, which allows the organisms to 241 maintain beneficial physiological conditions during the spawning and the post-spawning period 242 (Acevedo et al., 2007).

243 No significant differences between the length at first sexual maturity of males ( $34.35 \mathrm{~cm}$ of $L_{F}$ ) 244 and females ( $34.60 \mathrm{~cm} L_{F}$ ) were found; therefore, it is adequate to use a length at first sexual 245 maturity of the population ( $\left.34.40 \mathrm{~cm} L_{F}\right)$. According to the growth estimates of Euthynnus 246 alletteratus of the southwest Gulf of Mexico (Alcaráz-García, 2012), these sizes correspond to 247 an age of approximately two years. This data is relevant since, although the length at first sexual 248 maturity of this study strongly differed compared to estimates of the western Mediterranean Sea 249 (56 cm $L_{F}$ : Valeiras \& Abad, 2006), the Gulf of Cadiz (57 $\mathrm{cm} L_{F}$ : Rodríguez-Roda, 1966), the 250 Gulf of Guinea ( $\sim 3 \mathrm{~cm} L_{T}$ : Chur, 1973), and the coasts of Senegal (40 $\mathrm{cm} L_{T}$ : Diouf, 1981), sex 251 maturity occurs at about two years of age. These results demonstrate that E. alletteratus 252 specimens of the southwest Gulf of Mexico reproduce at the same age like the rest of the 253 populations of the eastern Atlantic, but at a length between 15 and $65 \%$ smaller, which coincides 254 with the hypothesis that tropical fish tend to be smaller and with wider reproductive periods than 255 those of greater latitudes (Kokita, 2004; Watt et al., 2010; Weber et al., 2015) or zones of higher 256 biological productivity (Geist, 1987; Garvey \& Marschall, 2003).

257 For E. alletteratus in the southwest Gulf of Mexico, it was observed that the changes in the 258 259 260 261 262 263 gonad $\left(I_{G}\right.$ and the increase in RG) that unchain the reproductive period start when SST rises to approximately 24 to $25^{\circ} \mathrm{C}$, reaching their maximum activity at about $28^{\circ} \mathrm{C}$ and decline abruptly above this threshold. This means that the optimum thermal window for E. alletteratus reproduction in the southwest Gulf of Mexico is asymmetric, skewed towards high temperatures, and occurs in a temperature range from 24 to $28^{\circ} \mathrm{C}$; beyond this range, the process is deactivated.

The extended reproductive period for E. alletteratus in the southwest Gulf of Mexico (five to six months), compared to populations in the eastern Atlantic ( $\sim 3.5$ months), is due precisely to the temporal extension of the optimum thermal window in each distribution area of this species. Gunter (1957) mentioned that the small seasonal variability could increase the possibility of finding specimens in reproduction in any season of the year as a direct response induced by the temperature over the metabolic rate. There is a relation between the span of the reproduction season, the type of spawning, and the latitude; thus, at high latitudes (brief summer period), the fish species have short, massive and well defined spawning periods (Cushing, 1975; Blaxter \& 
272 Hunter, 1982). However, at lower latitudes (subtropical and tropical areas), periods of

273 reproduction are prolonged and may be limited to a broader season, but with partial spawning, 274 such as we recorded for E. alletteratus in the southwest Gulf of Mexico. In some cases, it may 275 last the whole year (Cushing, 1975).

276

277 Conclusions

278 E. alletteratus distributed in the southwest Gulf of Mexico has an extensive reproductive period 279 of six months, lasting from April to September, with plausible evidence of two peaks that show 280 the increase in reproductive activity, one occurs in April and the main one in July. E. alletteratus 281 reaches its sexual maturity at $34.40 \mathrm{~cm} L_{F}$, without significant differences between sexes.

282 However, although the length at first sexual maturity is smaller than in the eastern Atlantic, the 283 age of first maturity of E. alletteratus in the southwest Gulf of Mexico is around two years and 284 therefore similar to that in the eastern region. Finally, the optimum thermal window for the 285 reproduction of this species ranges from 24 to $28^{\circ} \mathrm{C}$, determining the temporal extension of the 286 reproductive period.

287 Understanding the reproductive biology of the species is a crucial aspect to provide solid 288

289

290

291

292

293

294

295

296

297

298

299

300

301

302

303

304

305

306

307

308 scientific knowledge for fisheries management. In this sense, the results of this study allowed to get for the first time a detailed view about the reproductive dynamics of $E$. alletteratus inhabits the Gulf of Mexico. This key information will support future assessments for this species in Mexican waters, an allow us to design new strategies for its proper management.

\section{Acknowledgements}

The authors would like to recognize effort and support to all fishermen of Antón Lizardo, Veracruz, México. The authors also thank to M.C. Magnolia Salcedo Garduño for her help in processing samples and to M.C. Ana Gabriela Galicia Cruz for her support in graphics edition.

\section{References}

Acevedo, J., W. Angulo, M. Ramírez \& L.A. Zapata. 2007. Reproducción del pez Brotula clarkae (Pisces: Ophidiidae) en el Pacífico colombiano. Rev. Biol. Trop., 55(3-4): 957967.

Alcaráz-García, Z.T.J. 2012. Edad, Crecimiento y Mortalidad natural del bonito Euthynnus alletteratus (Rafinesque, 1810) en el suroeste del Golfo de México. Tesis de Maestría. Universidad Veracruzana, Instituto de Ciencias Marinas y Pesquerías, Boca del río, Veracruz, México.

Arellano-Martínez, M., A. Rojas-Herrera, F. García-Domínguez, B. Ceballos-Vázquez \& M. Villalejo-Fuerte. 2001. Ciclo reproductivo del pargo lunarejo Lutjanus guttatus (Steindachner, 1869) en las costas de Guerrero, México. Rev. Biol. Mar. Oceanog., 36(1): $1-8$. 
309

310

311

312

313

314

315

316

317

318

319

320

321

322

323

324

325

326

327

328

329

330

331

332

333

334

335

336

337

338

339

340

341

342

343

344

345

346

347

348

Bahou, L., T. Koné, V. N’Douba, K.J. N’Guessan, E.P. Kouamélan \& G.B. Gouli. 2007. Food composition and feedings habits of little tunny (Euthynnus alletteratus) in continental shelf waters of Côte d'Ivoire (West Africa). Ices J. Mar. Sci., 64: 1044-1052.

Bakhayokho, M. 1983. Biology of the cuttlefish Sepia officinalis hierredda off the Senegal coast. Fao Fish. Tech. Pap., 231: 204-263.

Belloc, G. 1955. Les thons de la Méditerranée. Deuxième note: Thonine et Bonite. FAO Proc. Gen. Fish. Counc. Medit., 3(52): 471-486.

Bezerra, N.P.A., C.A.F. Fernandes, F.V. Albuquerque, V. Pedrosa, F. Hazin \& P. Travassos. 2013. Reproduction of Blackfin tuna Thunnus atlanticus (Perciformes: Scombridae) in Saint Peter and Saint Paul Archipelago, Equatorial Atlantic, Brazil. Rev. Biol. Trop., 61(3): 1327-1339.

Blaxter, J.H.S. \& J.R. Hunter. 1982. The biology of the clupeoid fishes. Adv. Mar. Biol., 20: 1223.

Bouchot-Alegria, J.P. 2012. Dieta del bonito (Euthynnus alletteratus, Rafinesque 1810) capturado en el Sistema Arrecifal Veracruzano y áreas adyacentes. Tesis de Licenciatura. Instituto Tecnológico de Boca del Río, Boca del río, Veracruz, México.

Briarty, L.G. 1975. Stereology: methods for quantitative light and electron microscopy. Sci. Prog., 62: 1-32.

Cabrera, M.A., O. Defeo, F. Aguilar \& J. De Dios-Martínez. 2005. La pesquería del bonito (Euthynnus alletteratus) del noreste del banco de Campeche, México. Proceed. 47th Gulf and Caribbean Fish. Instit., pp. 744-759.

Cáceres-Martínez, J.A. \& A. Figueras. 1998. Long-term survey on wild and cultured mussels (Mytilus galloprovincialis Lmk) reproductive cycles in the Ria de Vigo (NW Spain). Aquaculture., 162: 141-156.

Cayré, P.M. \& T. Diouf. 1983. Estimating age and growth of little tunny, Euthynnus alletteratus, off the coast of Senegal using dorsal fin spine sections. NOAA Tech. Rep. NMFS SSRF., 8: 105-110.

Chur, V.N. 1973. Some biological characteristics of little tuna (Euthynnus alletteratus Rafinesque, 1810) in the eastern part of the tropical Atlantic. Collect. Vol. Sci. Pap. ICCAT., 1: 489-500.

Collette, B.B. \& C. Nauen. 1983. FAO Species catalogue, Scombrids of the world. An annotated and illustrated catalogue of tunas, mackerels, bonitos and related species known to date. FAO Fish. Syn., 2(125): 5-137.

Cruz-Castán, R.M., S. Curiel-Ramírez \& C. Meiners-Mandujano. 2014. Modificación de los tiempos de tinción de cortes histológicos con hematoxilina-eosina para maximizar la observación de gametos femeninos de Euthynnus alletteratus Rafinesque, 1810 (Pisces:Scombridae) del suroeste del Golfo de México. MES., 9(2): 7-12.

Curiel-Ramírez Gtz, S. \& J, Cáceres-Martínez. 2004. Reproductive cycle of coexisting mussels Mytilus californianus and Mytilus galloprovincialis in Baja California, NW. Mexico. J. Shell. Fish. Res. 23(2): 515-520. 
349

350

351

352

353

354

355

356

357

358

359

360

361

362

363

364

365

366

367

368

369

370

371

372

373

374

375

376

377

378

379

380

381

382

383

384

385

386

Curiel-Ramírez Gtz, S. \& J, Cáceres-Martínez. 2012. Asentamiento y dispersión de mejillones en Baja California, México. Editorial Académica Española. 133 pp.

Cushing, D.H. 1975. Marine ecology and fisheries. Cambridge University, Gran Bretaña. 278 pp.

Diouf, T. 1981. Premieres donnees relatives a l'exploitation et a la biologie de quelques "petits thonidés et especes voisines": Euthynnus, Sarda, Scomberomorus au Senegal. Collect. Vol. Sci. Pap. ICCAT., 15 (2): 327-336.

Falutano, M., L. Castriota, M. Grazia \& F. Andaloro. 2007. Feeding ecology of little tunny Euthynnus alletteratus in the central Mediterranean Sea. J. Mar. Biol. Assoc. UK., 87: 999-1005.

Frade, F. \& E. Postel. 1955. Contribution à l'étude de la reproduction des scombridés et thonidés de l'Atlantique tropical. Rap. Proces., 137: 33-35.

Froese, R. \& D. Pauly (ed). 2014. FishBase. http://www.fishbase.org/summary/97. Accessed 1 November 2014.

García, C.B. \& C. Posada. 2013. Diet and feeding ecology of the little tunny, Euthynnus alletteratus (Pisces: Scombridae) in the central Colombian Caribbean: changes in 18 years. Lat. Am. J. Aquat. Res., 41(3): 588-594.

Garvey, J.E. \& E.A. Marschall. 2003. Understanding latitudinal trends in fish body size through models of optimal seasonal energy allocation. Can. J. Fish. Aquat. Sci., 60: 938-948.

Gaykov, V.Z. \& D.V. Bokhanov. 2008. The biological characteristic of Atlantic black skipjack (Euthynnus alletteratus) of the eastern Atlantic Ocean. Collect. Vol. Sci. Pap. ICCAT., 62(5): 1610-1628.

Geist, V. 1987. Bergmann's rule is invalid. Can. J. Zool., 65: 1035-1038.

Granado-Lorencio, C. 1996. Ecología de peces. Estrategias de vida. Universidad de Sevilla, Sevilla, 317 pp.

Gunter, G.G. 1957. Temperature. In: J.W. Hedgpeth (ed.). Marine Ecology. Treatise on Marine Ecology and Paleoecology. Geol. Soc. Am. Mem., pp. 159-184.

Hajjej, G., A. Hattour, H. Allaya, O. Jarboui \& A. Bouain. 2010a. Biology of little tunny Euthynnus alletteratus in the Gulf of Gabes, Southern Tunisia (Central Mediterranean Sea). Rev. Biol. Mar. Oceanogr., 45(3): 399-406.

Hajjej, G., A. Hattour, H. Allaya, O. Jarboui, C. Mourad \& A. Bouain. 2010b. Length weight relationships for 13 fish species from the Gulf of Gabes (Southern Tunisia, Central Mediterranean). Afr. J. Biotechnol., 9(37): 6177-6181.

Introzzi, A.R. \& G. De Introzzi. 1986. Estudio de las concentraciones de los ácidos nucleicos (RNA, DNA) en músculo blanco e hígado de la lisa (Mugil brasiliensis) a lo largo de sus periodos de reposo y maduración gonadal. Rev. Invest. Desarr. Pesq., 6:117-129.

Jiménez-Badillo, M.L., H. Pérez-España, J.M. Vargas-Hernández, J.C. Cortés-Salinas \& P.A. Flores-Pineda. 2006. Catálogo de especies y artes de pesca del Parque Nacional Sistema Arrecifal Veracruzano. Conabio, Universidad Veracruzana, México, 182 pp. 
387

388

389

390

391

392

393

394

395

396

397

398

399

400

401

402

403

404

405

406

407

408

409

410

411

412

413

414

415

416

417

418

419

420

421

422

423

424

425

426

Kahraman, A.E. 2005. Preliminary investigations on Atlantic black skipjack (Euthynnus alletteratus raf. 1810) in the eastern Mediterranean Sea. Collect. Vol. Sci. Pap. ICCAT., 58(2): 502-509.

Kahraman, A.E., T.Z. Alicli, T. Akayli \& I.K. Oray. 2008. Reproductive biology of little tunny, Euthynnus alletteratus (Rafinesque), from the north-eastern Mediterranean Sea. J. Appl. Ichthyol., 24: 551-554.

Kahraman, A.E. \& I.K. Oray. 2001. Age and growth of Atlantic little tunny (Euthynnus alletteratus Raf., 1810) in Turkish waters. Collect. Vol. Sci. Pap. ICCAT., 49: 719-732.

Kokita, T. 2004. Latitudinal compensation in female reproductive rate of a geographically widespread reef fish. Environ. Biol. Fish., 71: 213-224.

Landau, R. 1965. Determination of age and growth rate in Euthynnus alletteratus and Euthynnus affinis using vertebrae. Rap. Proces. 18(1): 241-244.

Lowe, D.M., M.N. Moore \& B.L. Bayne. 1982. Aspects of gametogenesis in the marine mussel, Mytilus edulis. J. Mar. Biol. Assoc. UK., 62: 133-145.

Lucano-Ramírez, G., S. Ruiz-Ramírez \& J.A. Rojo-Vázquez. 2005. Biología reproductiva de Prionotus ruscarius (Pisces: Triglidae) en las costas de Jalisco y Colima, México. Rev. Dig. Univ., 6: 1067-1079.

Macías, D., L. Lema, M.J. Gómez-Vives, J.M. Ortiz de Urbina \& J.M. De la Serna. 2006. Some biological aspects of small tunas (Euthynnus alletteratus, Sarda sarda \& Auxis rochei) from the south western Spanish Mediterranean. Collect. Vol. Sci. Pap. ICCAT., 59(2): 579-589.

Macías, D., J.M. Ortiz de Urbina, M.J. Gómez-Vives, L. Godoy \& J.M. De la Serna. 2009. Size distribution of Atlantic little tunny (Euthynnus alletteratus) caught by south western Mediterranean traps and recreational trawl fishery. Collect. Vol. Sci. Pap. ICCAT., 64(7): 2284-2289.

Manooch, C.S., D.L. Manson \& R.S. Nelson. 1985. Food of Little Tunny (Euthynnus alletteratus) Collected along the Southeastern and Gulf Coast of the United States. B. Jpn. Soc. Sci. Fish., 51(8): 1207-1218.

Muñoz, A.P., E. Criscuolo, G.A. Wills, H.O. Mojica, J.F. González, J.H. Gamboa, J.A. Rodríguez, J.A. Senhorini, J. Valverde, J. Botero, M.A. Landines, P.E. Cruz, R. Rosado, S. Zimmermann \& Y.M. Velasco. 2005. Reproducción de los peces en el trópico. INCODER, Bogotá, Colombia.

Neves dos Santos, M. \& A. García. 2006. Observations on the catches of small tunas from a trap off The Algarve (southern Portugal). Collect. Vol. Sci. Pap. ICCAT., 59(3): 802-812.

Nikolsky. 1963. The ecology of fishes. Academic press, Great Britain, London, 352 pp.

Pascual, L., S. Saber, M.J. Gómez-Vives \& D. Macías. 2010. Estimación de dos parámetros reproductivos: edad y talla de primera madurez y fecundidad; en el bonito atlántico (Sarda sarda) capturados en almadrabas del Mediterráneo Español durante 2008-2009. Joint GFCM/ICCAT Expert meeting on small tuna fisheries in the Mediterranean, Madrid, SCRS/2010/129. 
427

428

429

430

431

432

433

434

435

436

437

438

439

440

441

442

443

444

445

446

447

448

449

450

451

452

453

454

455

456

457

458

459

460

461

462

463

464

465

Posada-Peláez, C., A. Santafé-Muñoz, M. Grijalba-Bendeck, D. Bustos-Montes, E. GonzálezSarmiento, J. De La Hoz-Maestre, L. Castro-Martínez, C. Gómez-Cubillos, P. GuerreroBernal, C. Olaya-Reyes, C.M. Palacio-Barros \& D. Restrepo-Gómez. 2012. Aspectos biológicos de las principales especies comerciales de la zona costera del departamento del Magdalena, Caribe colombiano. En: Grijalba-Bendeck M., D. Bustos-Montes, C. PosadaPeláez \& A. Santafé-Muñoz (eds). La pesca artesanal marítima del departamento del Magdalena: una visión desde cuatro componentes, pp. 354-365. Universidad de Bogotá Jorge Tadeo Lozano, Santa Marta. http://avalon.utadeo.edu.co/servicios/ebooks/pesca_artesanal/files/assets/basic$\underline{\mathrm{html} / \text { page } 356 . \mathrm{html}}$

Rodríguez-Roda, J. 1966. Estudio de la Bacoreta, Euthynnus alletteratus (Raf), Bonito, Sarda sarda (Bloch) y melva Auxis thazard (Lac), capturados por las almadrabas españolas. Inv.. Pesq., 30: 247-292.

Rodríguez-Roda, J. 1979. Edad y crecimiento de la Bacoreta, Euthynnus alletteratus (Raf.) de la Costa sudatlántica de España. Invest. Pesq., 43:591-599.

Sabatés, A. \& L. Recasens. 2001. Seasonal distribution and spawning of small tunas, Auxis rochei (Risso) and Sarda sarda (Bloch) in the Northwestern Mediterranean. Sci. Mar., 65(2): 95-100.

Saber, S., Ortíz de Urbina, J., Gómez-Vives, M.J. \& Macías, D. 2015a. Some aspects of the reproductive biology of albacore Thunnus alalunga from the western Mediterranean Sea. UK (JMBA). 95(8):1705-1715.

Saber, S., D. Macías, J. Ortiz de Urbina \& O.S. Kjesbu. 2015b. Stereological comparison of oocyte recruitment and batch fecundity estimates from paraffin and resin sections using spawning albacore (Thunnus alalunga) ovaries as a case study. J. Sea. Res. 95: 226-238.

Sampedro, M.P., V. Trujillo \& M. Saínza. 2005. INBIO: Software para estimación de incertidumbre de parámetros biológicos. Documento Interno del Instituto Español de Oceanografía, España.

https://www.researchgate.net/publication/304796071_A simple tool to calculate biolo gical_parameters' uncertainty_INBIO

Santamaría-Miranda, A. \& A.A. Rojas-Herrera. 1997. Análisis de la variación morfológica del huachinango, Lutjanus peru (Nichols y Murphy, 1922) (Pisces: Lutjanidae) en el litoral de la costa chica de Guerrero, México. Periodo noviembre 1992-diciembre 1994. Sociedad Ictiológica Mexicana. Resúmenes del V Congreso Nacional de Ictiología. Mazatlán, Sinaloa, México. 170 pp.

Seed, R. \& T.H. Suchanek. 1992. Population and community ecology of Mytilus. In: E. Gosling (ed.). The mussel Mytilus: ecology: ecology, physiology, genetics, and culture. Elsevier, Amsterdam, pp. 87-157.

Shaw, B.L. \& H.I. Batle. 1957. The gross and microscopic anatomy of the digestive tract of the oyster Crassostrea virginica (Gmelin). Can. J. Zool., 35: 325-347. 
466 Valeiras, J. \& E. Abad. 2006. Descripción de la bacoreta. In: Publicaciones ICCAT eds. Manual 467 de ICCAT Collect. Vol. Sci. Pap. ICCAT., 243-250.

468 Valeiras, X., D. Macías, M.J. Gómez, L. Lema, D. Godoy, J.M. Ortiz de Urbina \& J.M. De la 469 Serna. 2008. Age and growth of Atlantic little tuna (Euthynnus alletteratus) in the 470 western Mediterranean Sea. Collect. Vol. Sci. Pap. ICCAT., 62(5): 1638-1648.

471 Watt, C., S. Mitchell \& V. Salewsky. 2010. Bergmann's rule: A concept cluster? Oikos, 119:89472100.

473 Weibel, E.R., G.S. Kistler \& W.F. Scherle. 1966. Practical stereological methods for 474 morphometric cytology. J. Cell. Biol., 30: 23-38.

475 Weber, M.J., M.L. Brown, D.H. Wahl \& D.E. Shoup. 2015. Metabolic theory explains latitudinal 476 variation in common carp populations and predicts responses to climate change.

478 479 Ecosphere, 6(4): 54.

Zengin, M. \& F.S. Karakulak. 2009. Preliminary study on the Atlantic black skipjack (Euthynnus alletteratus, Rafinesque, 1810), caught by common purse seine fisheries in the north-

482 eastern Mediterranean coast of Turkey. Collect. Vol. Sci. Pap. ICCAT., 64 (7): 22112220 . 


\section{Figure 1}

Fishing ground location of E. alletteratus caught in the southwest Gulf of Mexico.

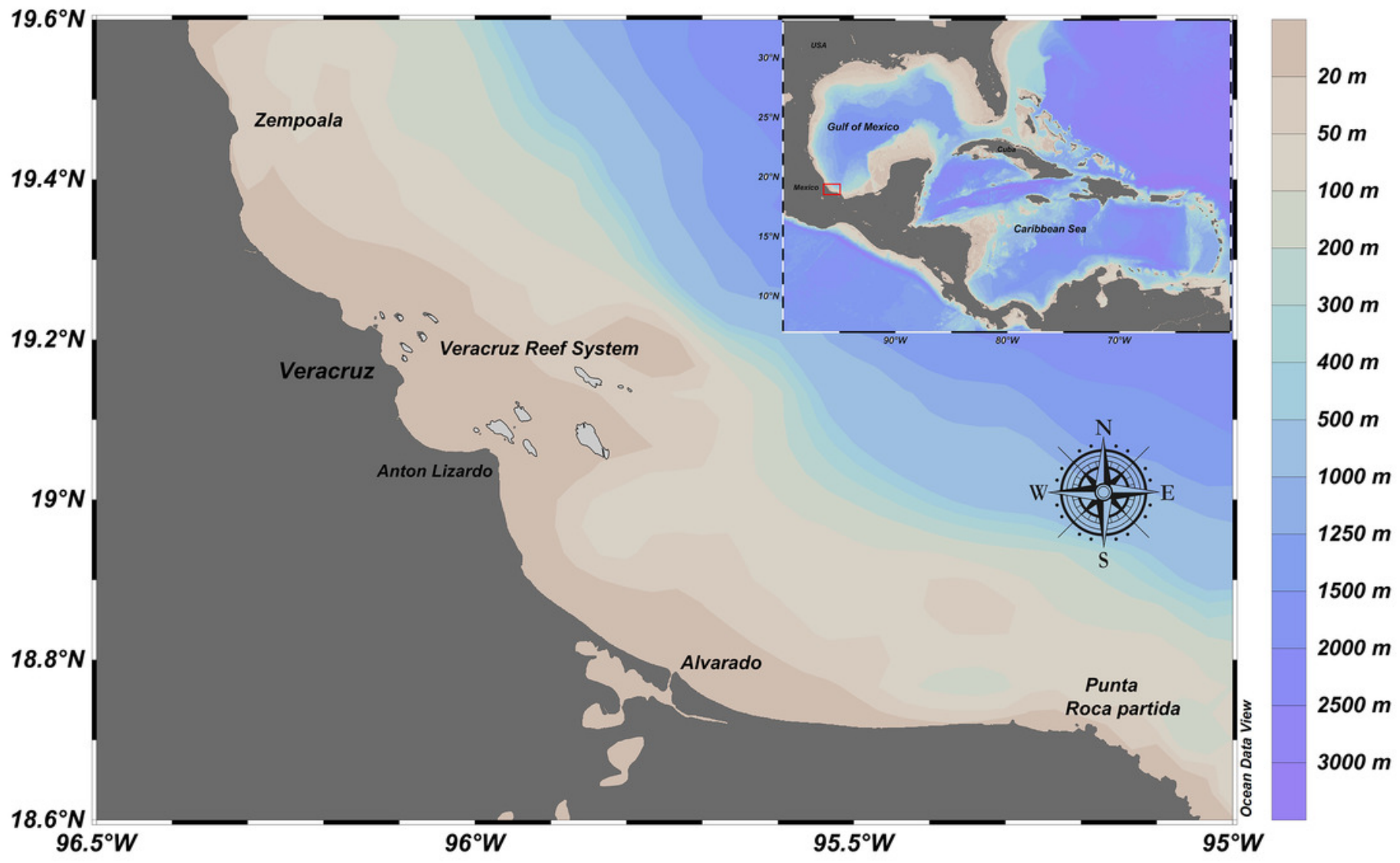


Figure 2

Length frequency distribution of $E$. alletteratus caught from December 2009 to November 2012 in the southwest Gulf of Mexico.

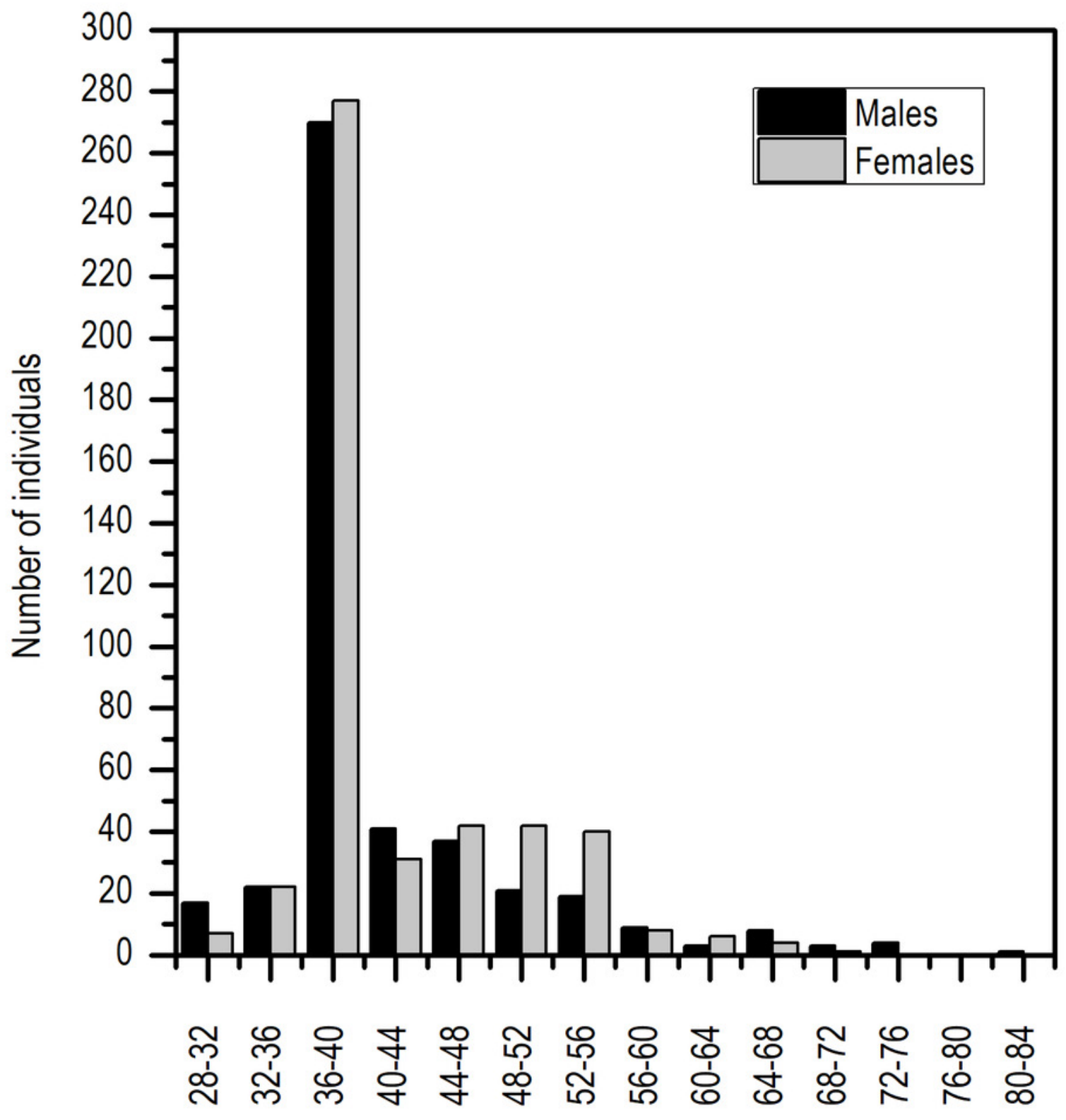

Fork length $(\mathrm{cm})$ 
Figure 3

Sex ratio of E. alletteratus caught from December 2009 to 2012 in the southwest Gulf of Mexico.

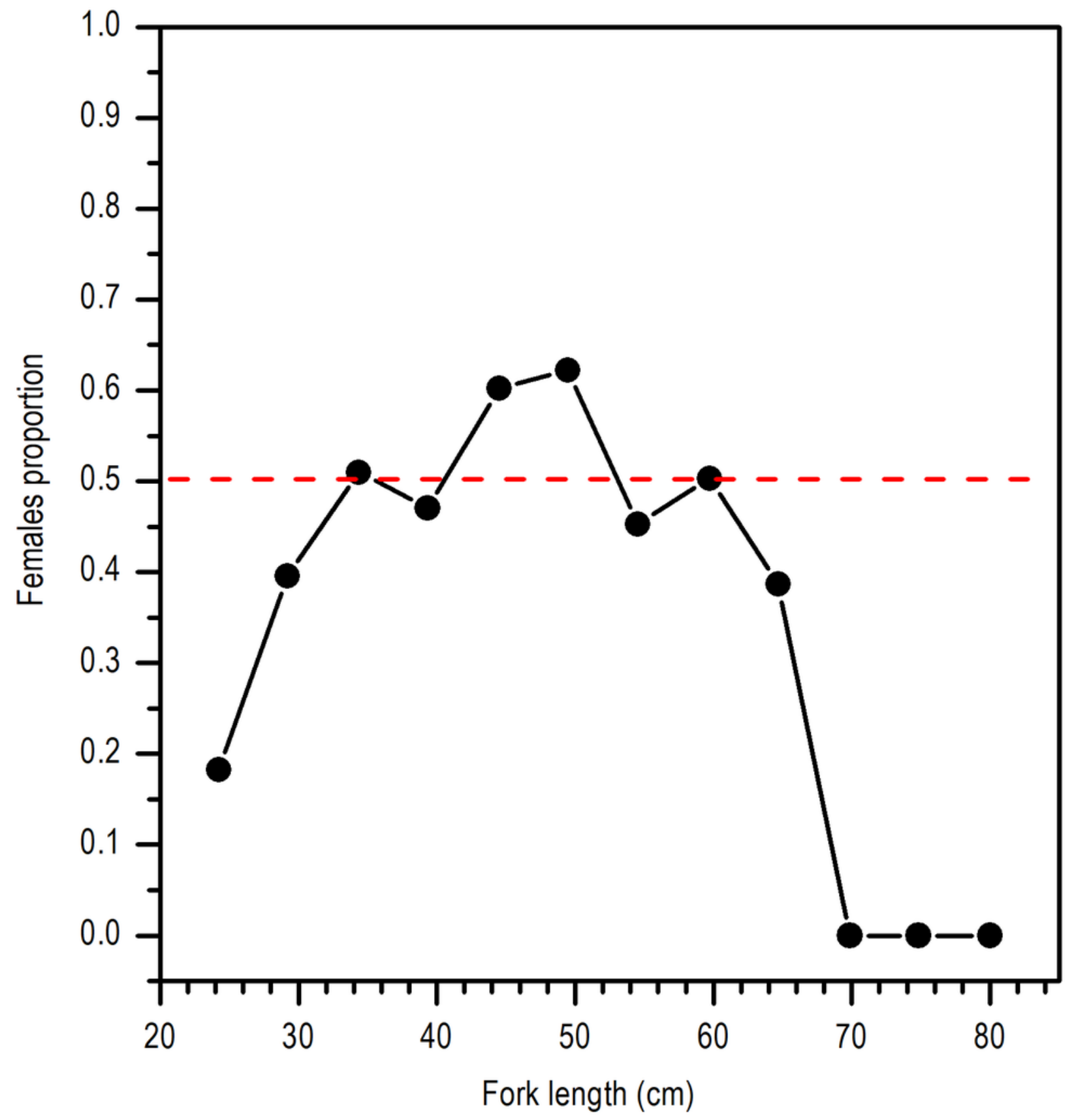




\section{Figure 4}

Monthly changes in the gonado-somatic index $\left(I_{G}\right)$, Hepato-somatic index $\left(I_{H}\right)$, and nutritional index $\left(I_{N}\right)$ for $E$. alletteratus caught from December 2009 to November 2012 in the southwest Gulf of Mexico.
(A) Males. (B) Females. 


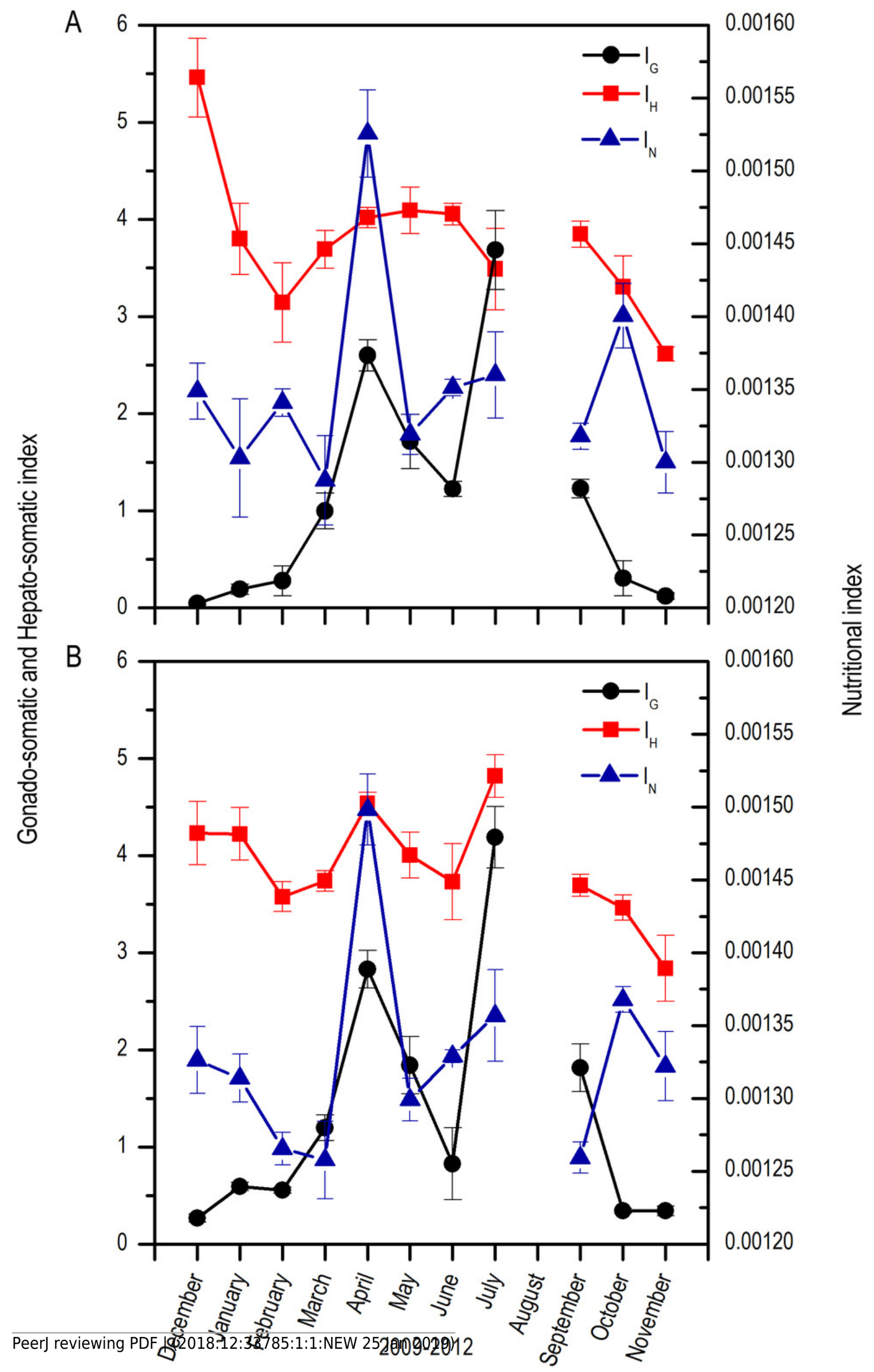


Figure 5

Size at sexual maturity $\left(\mathrm{L}_{50}\right)$ for females and males of $E$. alletteratus caught from December 2009 to November 2012 in the southwest Gulf of Mexico.

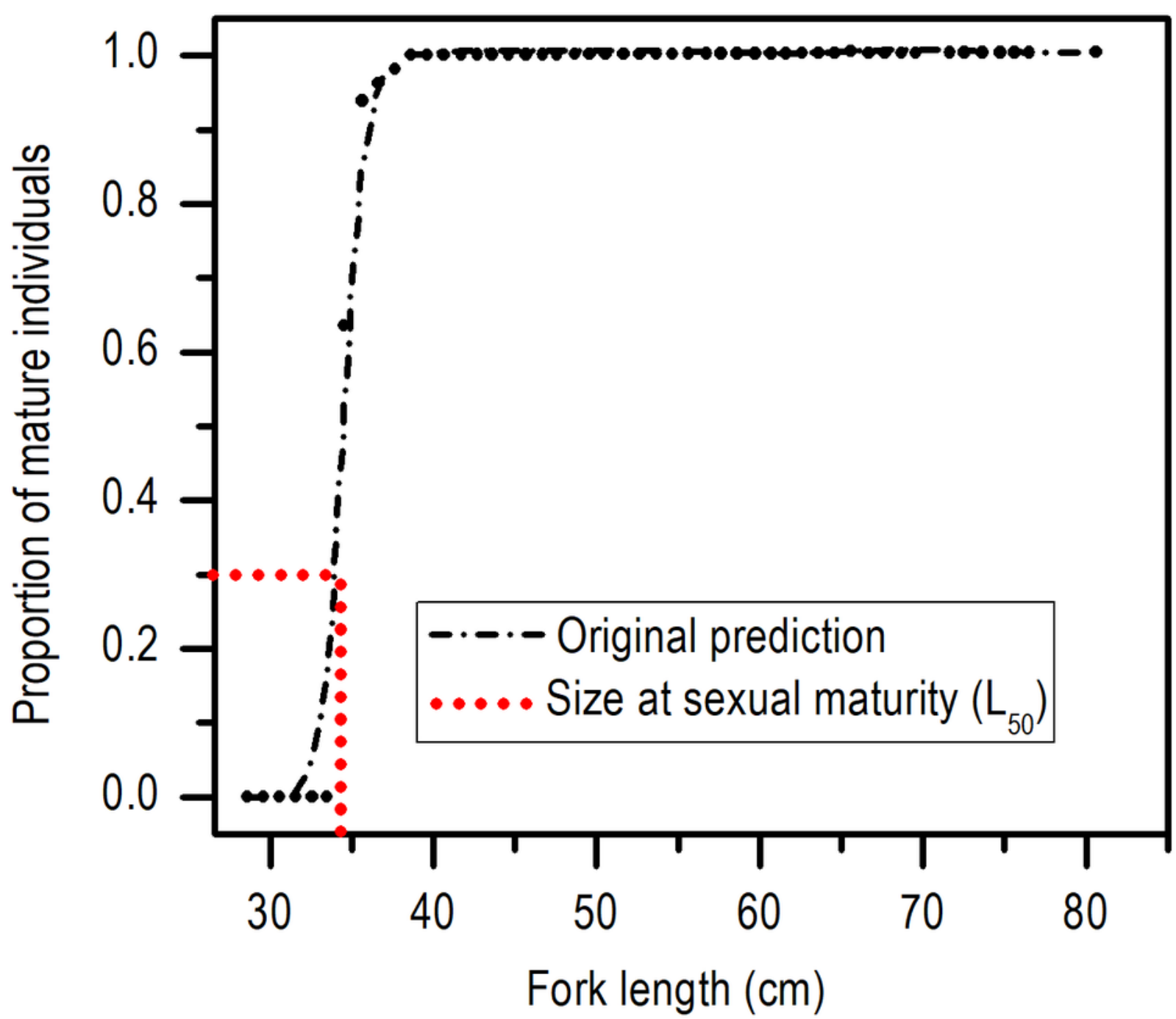


Figure 6

Variation of the volume percentage of main histologic components of $E$. alletteratus caught from December 2011 to November 2012 in the southwest Gulf of Mexico.

Ripe gametes (RG), Unripe gametes (UG), Free spaces (FS), and Vesicular connective tissue (VCT).

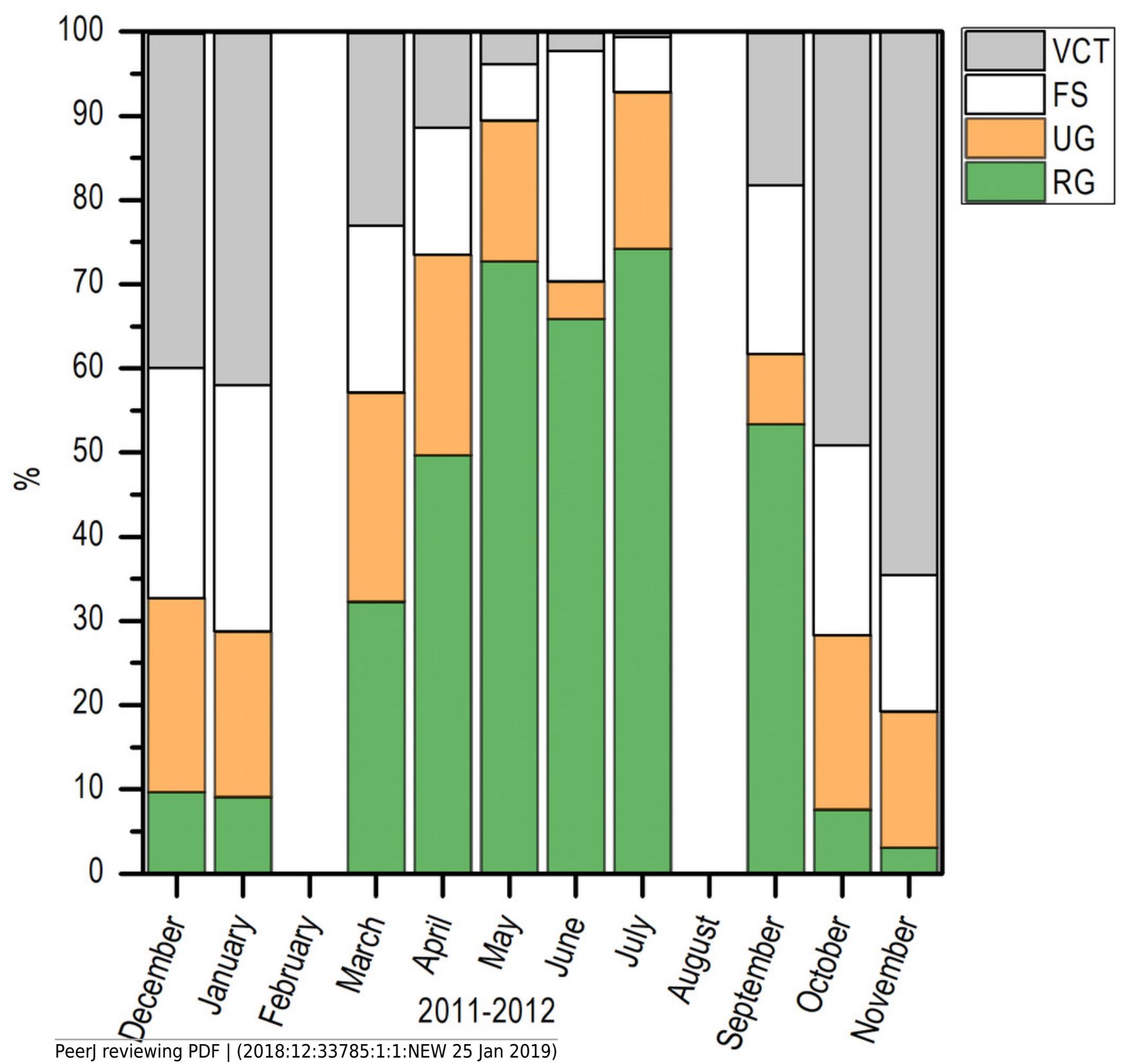


Figure 7

Relation between monthly changes in the sea surface temperature (SST) and the gonado-somatic index (IG) for E. alletteratus caught from December 2009 to November 2012 in the southwest Gulf of Mexico.

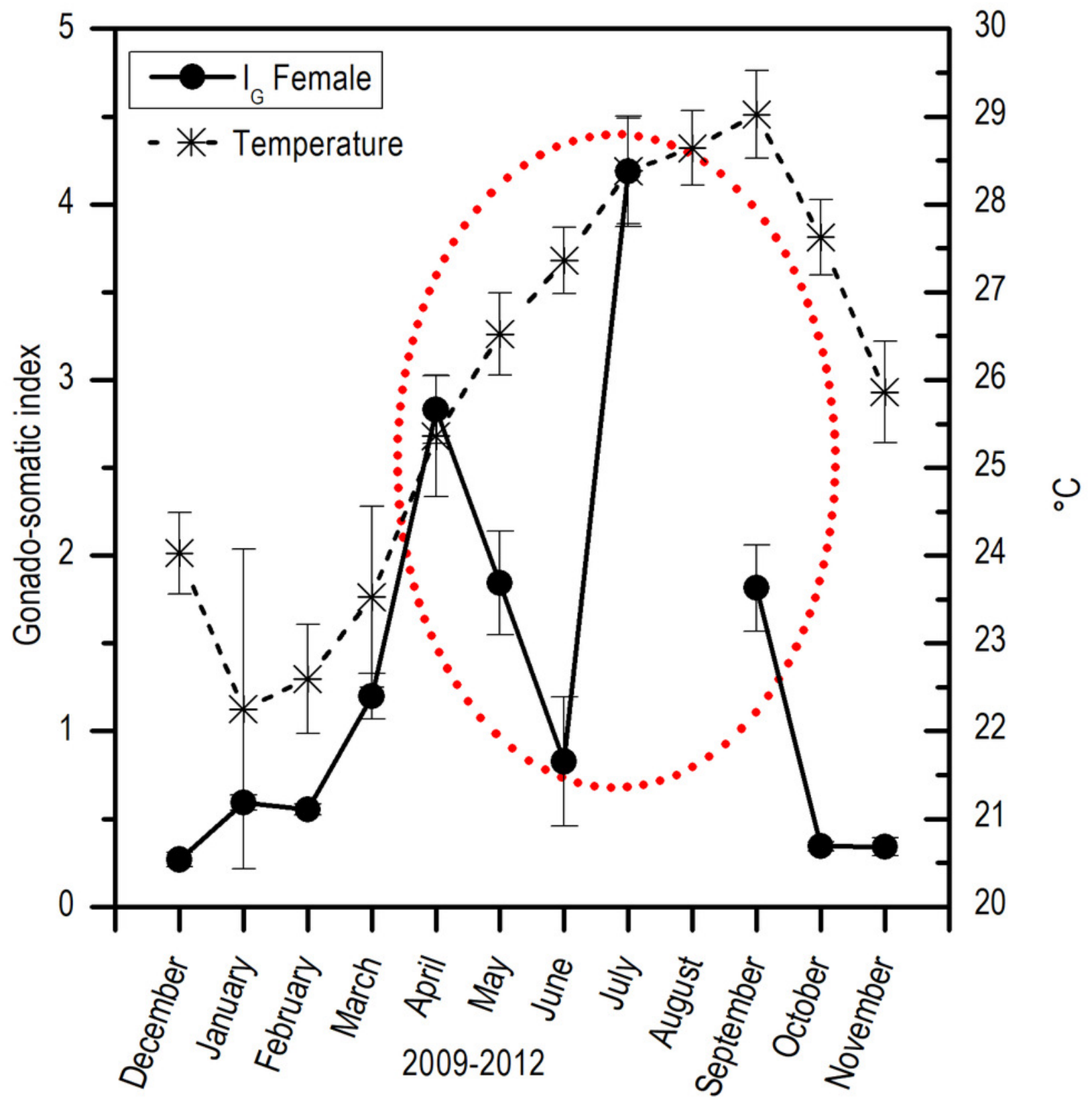


Figure 8

Monthly variation of ripe gametes percentages of $E$. alletteratus caught from December 2011 to November 2012 in the southwest Gulf of Mexico.

The red line represents the relationship fitted to a Gaussian model.

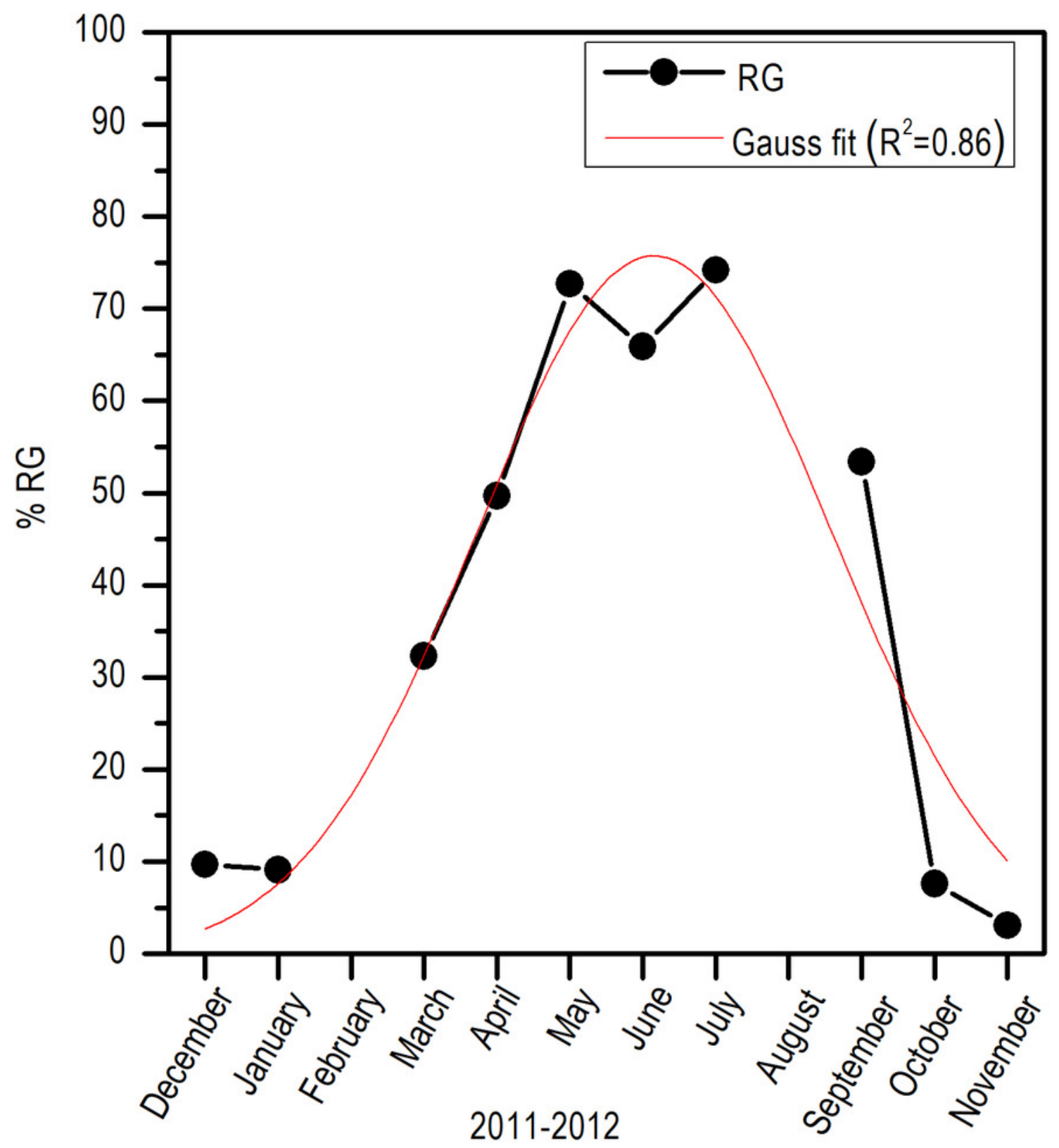




\section{Table $\mathbf{1}$ (on next page)}

Macroscopic scale to determine the maturity in the gonads of $E$. alletteratus caught from December 2011 to November 2012 in the southwest Gulf of Mexico, adapted from Bezerra et al. (2013) 
1 Table 1:

2 Macroscopic scale to determine the maturity in the gonads of Euthynnus alletteratus caught

3 from December 2011 to November 2012 in the southwest Gulf of Mexico, adapted from

4 Bezerra et al. (2013).

\begin{tabular}{|c|c|c|c|c|}
\hline $\begin{array}{c}\text { Maturity } \\
\text { status }\end{array}$ & Activity & Gonadal phase & Female & Male \\
\hline Immature & Inactive & Immature & $\begin{array}{l}\text { - Small ovaries } \\
\text { - White to pink color } \\
\text { - Ovaries only located in } \\
\text { a small part at the } \\
\text { abdominal cavity }\end{array}$ & $\begin{array}{l}\text { - } \\
\text { translucent testes and } \\
\text { - Located in a small } \\
\text { part at abdominal } \\
\text { cavity }\end{array}$ \\
\hline Immature & Inactive & Maturation & $\begin{array}{l}\text { - Ovaries white to pink } \\
\text { color } \\
\text { - Ovaries larger than in } \\
\text { immature phase with } \\
\text { more solid consistency } \\
\text { and increasing in } \\
\text { volume } \\
\text { - Oocytes are not } \\
\text { distinguished yet }\end{array}$ & $\begin{array}{l}\text { - Testes located in } \\
\text { half abdominal } \\
\text { cavity } \\
\text { - White testes } \\
\text { - Sperm only visible if } \\
\text { testes are cut but not } \\
\text { by pressure }\end{array}$ \\
\hline Mature & Active & $\begin{array}{l}\text { Spawning } \\
\text { capable }\end{array}$ & $\begin{array}{l}\text { - Large ovaries, and } \\
\text { located in almost all the } \\
\text { abdominal cavity } \\
\text { - Yellow to orange in } \\
\text { color } \\
\text { - Oocytes can be } \\
\text { observed }\end{array}$ & $\begin{array}{l}\text { - Large testes, located } \\
\text { in almost all the } \\
\text { abdominal cavity } \\
\text { - White testes } \\
\text { - Sperm visible if } \\
\text { testes are pressed }\end{array}$ \\
\hline Mature & Active & Spawning & $\begin{array}{l}\text { - Ovaries with translucent } \\
\text { oocytes (hydrated } \\
\text { oocytes) }\end{array}$ & $\begin{array}{l}\text { - Similar } \\
\text { characteristics as } \\
\text { mature phase are } \\
\text { observed } \\
\text { - Testes increase in } \\
\text { volume }\end{array}$ \\
\hline Mature & Inactive & Post spawning & $\begin{array}{l}\text { - Red ovaries } \\
\text { - Ovaries decrease in } \\
\text { volume }\end{array}$ & $\begin{array}{l}\text { - Red testes } \\
\text { - Testes decrease in } \\
\text { volume } \\
\text { - Sperm not visible if } \\
\text { testes are pressed } \\
\end{array}$ \\
\hline Mature & Inactive & Rest & $\begin{array}{l}\text { - Pink to white ovaries } \\
\text { - Ovaries completely } \\
\text { located along the } \\
\text { abdominal cavity } \\
\text { - Ovaries decrease in } \\
\text { volume }\end{array}$ & $\begin{array}{l}\text { - White to pink testes } \\
\text { - Testes fully present } \\
\text { along the abdominal } \\
\text { cavity } \\
\text { - Testes decrease in } \\
\text { volume }\end{array}$ \\
\hline
\end{tabular}




\section{Table 2 (on next page)}

Main histologic components and their cellular stages in gonads of $E$. alletteratus caught from December 2011 to November 2012 in the southwest Gulf of Mexico, adapted from Saber et al. (2015b). 
1 Table 2:

2 Main histologic components and their corresponding cellular stages in gonads of 3 Euthynnus alletteratus caught from December 2011 to November 2012 in the southwest 4 Gulf of Mexico, adapted from Saber et al. (2015b).

\begin{tabular}{|c|c|c|}
\hline \multirow[t]{2}{*}{ Histologic component } & \multicolumn{2}{|c|}{ Cellular stages } \\
\hline & Female & Male \\
\hline Ripe gametes (RG) & $\begin{array}{l}\text { - Advanced vitellogenic } \\
\text { oocytes } \\
\text { - Migratory nucleus oocytes } \\
\text { - Hydrated oocytes }\end{array}$ & $\begin{array}{l}\text { - Spermatids } \\
\text { - Spermatozoa }\end{array}$ \\
\hline Unripe gametes (UG) & $\begin{array}{l}\text { - Primary growth oocytes } \\
\text { - Lipid-stage oocytes } \\
\text { - Early vitellogenic oocytes }\end{array}$ & $\begin{array}{l}\text { - Spermatogonia } \\
\text { - Spermatocytes }\end{array}$ \\
\hline Free space (FS) & $\begin{array}{l}\text { - Free space inside the } \\
\text { gonad }\end{array}$ & $\begin{array}{l}\text { - Free space inside the } \\
\text { gonad }\end{array}$ \\
\hline Vesicular connective tissue (VCT) & $\begin{array}{l}\text { - Connective tissue inside } \\
\text { the gonad }\end{array}$ & $\begin{array}{l}\text { - Connective tissue inside } \\
\text { the gonad }\end{array}$ \\
\hline
\end{tabular}

5 


\section{Table 3(on next page)}

Sample size, length and weight descriptors by sex for $E$. alletteratus caught in the southwest Gulf of Mexico from December 2009 to November 2012. 
1 Table 3:

2 Sample size, length and weight descriptors by sex for Euthynnus alletteratus caught in the 3 southwest Gulf of Mexico from December 2009 to November 2012.

\begin{tabular}{lccccc}
\hline \multicolumn{1}{c}{ Sex } & $\begin{array}{c}\text { Number of } \\
\text { individuals }\end{array}$ & Mean $\boldsymbol{L}_{\boldsymbol{F}}(\mathbf{c m})$ & Mean weight $(\mathbf{g})$ & $\begin{array}{c}\text { Range length } \\
(\mathbf{c m})\end{array}$ & $\begin{array}{c}\text { Range weight } \\
(\mathbf{g})\end{array}$ \\
\hline \hline Males & 455 & $41.48 \pm 7.98$ & $1209.09 \pm 996.57$ & $28.5-80.7$ & $350-8560$ \\
\hline Females & 480 & $41.96 \pm 7.05$ & $1195.02 \pm 730.56$ & $28.2-68.1$ & $340-4520$ \\
\hline Undetermined & 16 & $40.02 \pm 7.87$ & $1003.07 \pm 435.68$ & $28.9-52.0$ & $350-1840$ \\
\hline
\end{tabular}

4

5

6 